\title{
Vanguardia y crítica: Vida del ahorcado (novela subjetiva) de Pablo Palacio
}

\section{Vanguard and criticism: Vida del ahorcado (novela subjetiva) by Pablo Palacio}

\author{
Inkíngari Daniel Ayala Bertoglio \\ Universidad de Guanajuato, México
}

Resumen: Este texto propone una aproximación a dos aspectos fundamentales presentes en la obra de Pablo Palacio Vida del ahorcado (novela subjetiva): la ironía crítica y la narrativa de vanguardia. Mediante una breve ojeada al contexto de la época y al concepto de modernidad, se verá como ambas nociones se imbrican y representan una ruptura con la forma de escribir novelas, hasta entonces, en América Latina.

Palabras clave: vanguardia, narrativa, modernidad ironía, crítica.

Abstract: This paper proposes an approach of two fundamental aspects in the work of Pablo Palacio Vida del ahorcado (novela subjetiva): the critical irony and the narrative of vanguard. Through a brief look at the context of the epoch and the concept of modernity, we will see how these two notions overlap and represent a break with the way of writing novels, till then, in Latin America.

Keywords: Vanguard, Narrative art, Modernity, Irony, Criticism.

Recibido: 31 de diciembre de 2016 Aceptado: 15 de mayo de 2017 
Quien, en alguna forma, interviene en cualquiera de las actividades humanas, lo hace en virtud de principios, de creencias, que no aparecen en cada caso concreto, pero que residen en el fondo de nuestras determinaciones, regulándolas.

\section{El autor en su contexto}

$\mathrm{C}^{\mathrm{n}}$ n la actualidad, la obra de Pablo Palacio (Loja, Ecuador 19061947) goza de un prestigio indiscutible, muestra de ello son las seis ediciones que hasta el momento se han realizado de sus Obras completas ${ }^{1}$ y la cada vez más significativa cantidad de artículos académicos, ensayos y reseńas que al respecto se encuentran en las páginas de revistas tanto americanas como europeas. Este hecho, sin embargo, es un tanto reciente si tomamos en cuenta que la mayor parte de su obra fue escrita durante las décadas de años veinte y treinta, y que en su momento no tuvo una muy buena recepción por parte de la crítica.

El motivo del rechazo por parte de sus contemporáneos acaso se haya debido a la ruptura de cánones establecidos - hasta ese momento en la narrativa ecuatoriana- de la obra palaciana: en cuanto a forma, baste señalar el carácter fragmentario de los espacios, la temporalidad disruptiva o las voces atípicas de sus personajes; en lo que se refiere a los temas, la brutalidad, los asesinatos, la crítica

${ }^{1}$ Tomo aquí la edición: Pablo Palacio, 2000, Obras completas, W. H. Corral (ed.), ALLCA XX, Colección Archivos 41, Madrid, Barcelona, La Habana, Lisboa, Paris, México, Buenos Aires, Sao Paulo, Lima, Guatemala, San José, 620 pp. En ésta se revisan las ediciones anteriores; aunque existe una edición posterior: Obras completas, P. Herrera Crespo (ed.), UNAP, Quito, 336 pp., con motivo del centenario de su nacimiento. 
social..., una obra vanguardista, compleja y de difícil asimilación incluso en nuestra época.

El contexto mundial en que surge una personalidad como la de Palacio, así como su obra, es sumamente peculiar; apenas es necesario recordar los grandes debates latinoamericanos en torno al nacionalismo y el cosmopolitismo de la literatura y el arte en general, la explosión de los movimientos de vanguardia europeos, las innovaciones en materia narrativa de Joyce, Proust, Kafka, Borges..., las preocupaciones acerca del destino que tendrían los jóvenes países de Nuestra América, las revoluciones, las guerras mundiales y un sinfín de procesos socioculturales que aceleraron vertiginosamente la vida en los siglos XX y XXI. Respecto del contexto literario latinoamericano de la época escribe Hugo Verani:

La segunda década del siglo XX es un periodo clave e imprescindible para comprender el desarrollo actual de las letras latinoamericanas. Es la década en la que se descarta la suntuosa retórica preciosista del modernismo y se sientan las bases para una ruptura total con el pasado artístico inmediato; a partir de ella, las modalidades literarias dominantes reconocen la raíz común. Son los años del lanzamiento de manifiestos, de proclamas y de polémicas violentas, de una intensa búsqueda de originalidad, de insurgencia expresiva y formal que estalla en realizaciones que transforman radicalmente las letras del continente (1997: 10).

Muerto prematuramente -si pensamos en lo trascendente de una obra clausurada apenas a los 41 años de edad de su autor-, Palacio vivió intensamente la vida política y cultural del Ecuador, ese "chiquito país" que luchaba por encontrar la vía más idónea para su desarrollo y se debatía acremente entre el conservadurismo y el liberalismo. Sus circunstancias personales no son menos convulsas, con escasos tres años "se da el ínfimo accidente en la Chorrera del Pedestal, motivo de varia y constante especulación sobre el estado 
mental de Palacio (hasta su muerte) y la trascendencia de ese hecho en su obra" (Corral, 2000: 257). Hay que recordar que en dicho accidente, el pequeño sufre una fractura múltiple de cráneo al golpearse contra una roca, de ahí la errónea asociación de su estado mental con los tópicos y formas de su narrativa.

En su temprana adolescencia comienza su labor literaria con uno de sus primeros cuentos "El huerfanito" (1921) -en donde se hace alusión directa a su condición de hijo ilegítimo y de la muerte de su madre-, dicho cuento obtiene mención honorífica en los Juegos Florales de su ciudad natal; a estas primeras incursiones seguirán la colección de cuentos Un hombre muerto a puntapiés (1927), las novelas cortas Débora (1927) y Vida del ahorcado (1932), ${ }^{2}$ algunos relatos, poemas y ensayos filosóficos publicados en diversas revistas y periódicos como Hélice, Esfinge, Avance, entre otras; así como una traducción de fragmentos de Heráclito.

Palacio fue, asimismo, abogado de profesión, profesor de la Universidad Central del Ecuador, subsecretario de educación cuyo ministerio se encontraba a cargo de su amigo Benjamín Carrión- y miembro fundador del Partido Socialista Ecuatoriano; en suma, un espíritu inquieto hasta que los desórdenes mentales que lo aquejaban cobraron su vida en el hospital "Luis Vernaza" de Guayaquil el 7 de enero de 1947, cuando estaba a punto de cumplir 41 años. En las siguientes páginas, intentaré abordar dos aspectos de su obra que, pese a ser los que más saltan a la vista, no han sido tratados tan a fondo por los especialistas, me refiero a la potente crítica -social y literaria- y a la anomalía que supuso, en

\footnotetext{
${ }^{2}$ Aunque al parecer el título original de Vida del ahorcado (novela subjetiva) era Rumiantes de la sombra (novela) de acuerdo a un anuncio que se hace al final de Débora, no hay mucha información al respecto. También se ha mencionado la existencia de la novela inédita y aparentemente perdida: Ojeras de virgen, ganadora de los Juegos Florales del Centenario del Colegio Bernardo Valdivieso de 1926.
} 
el contexto literario ecuatoriano de la época, su obra; para ello me enfocaré en el análisis de Vida del ahorcado (novela subjetiva) pero también haré referencia a otros de sus escritos.

\section{Modernidad literaria y vanguardismo}

En el prefacio a su libro Los hijos del limo, Octavio Paz escribe: "la contradicción entre historia y poesía pertenece a todas las sociedades pero sólo en la edad moderna se manifiesta de una manera explícita" (1990: 9). Esa edad moderna a que se refiere Paz ha sido objeto de largos tratados y discusiones respecto a su definición, a su caracterización, sus principios, sus representantes y su posible fin; se acepta, no obstante, que su figura señera es Baudelaire, es él quien define el término -al menos en lo que se refiere al arte- y quien sienta las bases reflexivas al respecto: "la modernidad es lo transitorio, lo fugitivo, lo contingente, la mitad del arte, cuya otra mitad es lo eterno y lo inmutable" (1995: 92).

Hablar de modernidad lleva implícita la suposición de que existe una antigüedad, es decir, que lo moderno sería aquello que se opone a lo viejo; la lógica nos indicaría entonces que cada nuevo ser humano, o cada nueva generación, sería moderna con respecto a la anterior pero, en breve, dejaría de serlo, es decir, "la modernidad nunca es ella misma: siempre es otra" (Paz, 1990b: 18; cursivas en el original); de manera que la modernidad no podría -siguiendo ese razonamiento- ser una época, sino que sería un momento en constante cambio; llamamos "modernidad" a esta época "porque no hay una palabra mejor para expresar la idea en cuestión" (91), como escribiría el propio Baudelaire. Ahora bien, he querido recordar brevemente estas cuestiones porque serán de gran ayuda al momento de analizar las implicaciones contenidas en la obra de Pablo Palacio. 
Es un lugar común decir que una obra es "adelantada a su tiempo" cuando rompe con los cánones establecidos y aceptados de determinado momento histórico; volviendo a Paz, esa ruptura sería "destrucción del vínculo que nos une al pasado, negación de la continuidad entre una generación y otra" (1990b: 17). Así, con la modernidad se da una exaltación a la novedad como valor, el centro de las preocupaciones se desplaza, de la repetición de formas y temas previos, hacia la constante búsqueda de lo inesperado y la sorpresa; por tanto, no es raro encontrarse con la afirmación de que los movimientos de vanguardia -esto es, buscar ir siempre adelante- son el pináculo de lo moderno.

Con base en una lectura superficial, la obra de Palacio se ajustaría a las características mencionadas hasta el momento, su modernidad y su vanguardismo han sido ya ampliamente tratados por diversos críticos; sin embargo, es necesario insistir en las características propias de la obra y volver a pensar en ella, más allá de membretes que no siempre resultan productivos. Por principio de cuentas, es importante tener presente las condiciones vividas en el Ecuador de su tiempo en materia literaria, al respecto Humberto E. Robles resume:

Se sabe que entonces [hacia mediados de los años 20] prosperaba en el país el paradigma de una literatura de denuncia y protesta social que, a pesar de las espantosas condiciones de vida que exponía, reproducía fundamentalmente un sentido de realidad "convencional”. Al lector $-\mathrm{y}$ no serían muchos dado el alto nivel de analfabetismo de la época- se lo llevaba de la mano, se lo interpelaba. La función del mismo era la del receptor antes que la de un partícipe activo. El mundo representado en esas obras respondía a un sentido de organización y orden. Tenía lógica, tenía centro, y objetivos teleológicos, utópicos, de sanidad y reivindicación social. Ésa era la tendencia hegemónica y ésa era la tendencia que se promovía y auspiciaba (2000: 315). 
En este ambiente anquilosado y de complacencia, la escritura, los personajes y las estructuras narrativas de Palacio son anómalas; de acuerdo a la primera acepción que da el DRAE, anomalía es "discrepancia de una regla o de un uso"; no obstante, como ser verá a continuación, dicha discrepancia se muestra en Palacio de una manera sui géneris: si la directriz primordial de la literatura ecuatoriana era, en esos tiempos, la de un realismo social, crítico de las condiciones de vida de país, la obra de Palacio entra perfectamente en ese orden de ideas; no obstante, es la forma como se plantean las cuestiones críticas lo que hace su obra distintiva.

Por otro lado, si dicha literatura (la primera) tenía como postulado central una tradición narrativa, la de Palacio no desmerece; es decir, no rompe del todo con lo tradicional, al contrario, suscribe plenamente otro tipo de tradición incluso más antigua que el socialrrealismo, aquella que se refiere la crítica social -recuérdese, únicamente como ejemplo, que en materia de ironía crítica en lengua castellana el Barroco nos ha legado grandes exponentes-. ¿Cómo entonces justipreciar la obra del lojano? A decir de Celina Manzoni, una de las primeras críticas en dirimir estas relaciones: "La obra de Pablo Palacio se integra a un brillante periodo de la literatura ecuatoriana que en los años treinta logra realizar la quiebra del sistema literario vigente desde el siglo XIX desde dos perspectivas: la de la escritura vanguardista y la de la escritura del realismo social" (2000: 447).

\section{Anomalías}

Vayamos por partes; estructuralmente, Vida del ahorcado (novela subjetiva) se presenta de manera discontinua, la constituyen apartados que en un primer momento se podrían asociar con las entradas de un diario de acuerdo a los títulos que los abren: "PRIMERA MAÑANA DE MAYO”, “2”, “5”, “10”, sin embargo, el orden 
ascendente de estas primeras "entradas" rápidamente da paso a una multiplicidad de apartados aparentemente inconexos entre sí como "HAMBRE”, "PERRO PERDIDO”, "HOMbRE CON PULGAS", etc. Se presentan de manera aparentemente inconexa pues cada uno revela un sentido, cada uno se presenta como una pieza del gran collage que es la novela y nos permiten ser partícipes del mundo creado al interior de ésta, lejos ya del mimetismo o el reflejo; en este sentido, el relato es mínimo en cuanto a los hechos que se narran, sin embargo, el lirismo con el que está construida la trama realza los acontecimientos y los dota de un sentido mucho mayor que el lector desentrańa.

El final de la novela es igualmente sorpresivo, tal sorpresa se introduce mediante la nota: "Esta historia pasa de aquí a su comienzo, en la primera mańana de mayo; sigue a través de estas mismas páginas, y cuando llega de nuevo aquí, de nuevo empieza allá... Tal era su iluminado alucinamiento" (Palacio, 2000: 184). Un posible sentido de crear una estructura cíclica sería que esa vida del ahorcado no pertenece a un hombre en particular, sino que se crea la idea de que todo ser humano es, en sí mismo, un ahorcado; el recomienzo no se entiende, entonces, como vía positiva de resurgimiento, sino como símbolo de un estancamiento vital.

El primer desafío en la lectura se da justamente en tratar de desvelar el orden o la lógica de los fragmentos que componen la obra, sin embargo, ¿es necesario que exista un orden, una lógica? y si esto es así ¿de qué tipo deben ser? Con estos simples cuestionamientos vemos ya que el lector pasa de ser un simple espectador pasivo de la obra a uno con más participación, Palacio ha logrado el cometido de sacudir las telarańas de la cabeza del lector, la apelación a éste es ahora diferente, sin complacencias, pareciera decir "hipócrita lector" o: 
O D I O

Quiero entenebrecer la alegría de alguien.

Quiero turbar la paz del que esté tranquilo.

Quiero deslizarme calladamente en lo tuyo para que no tengas sosiego; justamente como el parásito que ha tenido el acierto de localizarse en tu cerebro y que te congestionará uno de estos días; sin anuncio ni remordimiento (149).

Como se sabe, uno de los rasgos característicos de todo movimiento de vanguardia es el lanzamiento de proclamas y manifiestos donde se expresan las intenciones artísticas de los miembros que conforman el grupo; entonces, el párrafo antes mencionado bien podría entrar en la definición de manifiesto, declaración de principios hacia el hipotético lector y poética de la obra en sí.

Otro aspecto igualmente significativo es el de la narración. En su mayoría, el hilo conductor corre a cargo del protagonista principal: Andrés Farinango. Sin embargo, como no se trata de una narración lineal y progresiva, hay diversos fragmentos con su propia voz, y otros que pertenecen a un imaginario colectivo. Por mediación de dicha multiplicidad de voces, el relato se va construyendo como una serie de estampas o planos cinematográficos; de igual forma, en ocasiones el fuerte tono conversacional remite en la novela a un cierto aire de oralidad.

Lo que más llama la atención es el tono dubitativo de la voz principal, desde el comienzo de la novela el yo de Andrés oscila entre unos momentos de gran lucidez y otros en donde se crea la sensación de que es otra voz -aunque sea la de él mismo o de un desdoblamiento de su personalidad- la que emerge y se adueña de la narración. Situándonos en el comienzo leemos:

Ahora bien: en este momento yo he despertado. Fue así de improviso, como hacer luz, como apagar la luz. Estiro la pierna, amigo 
mío, y veo en donde he despertado. Éste es un cubo parecido a aquel en que todos los hombres despiertan. Se puede ver aquí medianamente. Ya es de día. Ya es la hora de ayer, compañero. Está todo en su sitio.

Pero los párpados vuelven a cerrárseme, pero ya es la hora de ayer.

-Andrés - silba una voz bajita.

Me incorporo de un salto. Escucho. ¿Quién me ha llamado? Aquí no puede haber otra voz que la mía.

Retengo el aliento. Me levanto de puntillas, todos los sentido abiertos. Es preciso observar, que en este cubo hay algo peligroso (145).

Por medio de este fragmento inicial observamos uno de los rasgos más destacados de la novela -y en el que la gran mayoría de la crítica ha puesto sus ojos-, se trata de la evidencia de que el narrador, Andrés Farinango, es un demente o, más propiamente, un esquizofrénico pues como se sabe este tipo de trastorno ocasiona desvíos en la percepción de la realidad, alucinaciones auditivas o visuales y alteraciones en la lógica habitual del pensamiento.

Como mencioné líneas arriba, Palacio sufrió un accidente en la cabeza cuando apenas era un niño, con base en este hecho, cierta parte de los detractores del autor hicieron un paralelismo de ello con los tópicos y los personajes de sus relatos y novelas. ${ }^{3}$ Maniobra ésta bastante descontextualizada si recordamos el igualmente penetrante pensamiento de Palacio y su capacidad de discernimiento

\footnotetext{
${ }^{3}$ Recordemos por ejemplo los personajes extraños, locos, asesinos, antropófagos y demás que recurrentemente aparecen en los cuentos de Un hombre muerto a puntapiés o en la novela anterior Débora. Wilfrido H. Corral escribió al respecto: "Uno que otro crítico nacional que llegó a conocer a Palacio en persona ha referido varias versiones del hecho de que el autor tenía un hoyo en el cráneo, causado al ser arrastrado a la edad de tres años por la corriente del canal de la planta eléctrica de Loja. A veces [...] parece que si se conoce anécdotas como ésa, aquéllas han sido tomadas a pecho para interpretar al autor" (84).
} 
presente en los ensayos filosóficos Sentido de la palabra verdad y Sentido de la palabra realidad, ambos aparecidos en 1935 (posteriores a sus relatos y novelas). Acerca de su inteligencia y su peculiar forma de ver la vida, han quedado para la posteridad las palabras que su gran amigo Benjamín Carrión escribiera a propósito de nuestro autor (2001: 67-78).

La esquizofrenia de Farinango tiene otros propósitos e implicaciones. De entrada, el hecho de que el narrador de la novela tenga una condición -y una visión- al margen de lo socialmente establecido como "bueno" o "normal" sienta ya la base para su propia estructuración, como ya se ha señalado, ésta crea su propia lógica; es decir, subraya lo establecido en el subtítulo de la novela, su subjetividad. Al mismo tiempo, cuando el lector advierte que se encuentra con una dislocación de la realidad, entra en el mundo ficcional propuesto y se aleja cada vez más de lo convencional.

El pico más alto de paroxismo en el personaje se da en el apartado titulado "sueÑos", asimismo, se podría señalar éste como el centro gravitatorio de la trama y pieza clave para entender lo que podríamos llamar el desenlace. En un inicio, este episodio se construye, como su nombre lo indica, por medio de imágenes oníricas, sin embargo, tras un salto en blanco en la escritura, el personaje exclama: “¡Ya está aquí mi hijo! ¡Ya está aquí mi hijo! ¡Gentes de este lado del mundo, sabed que me ha nacido un hijo! Ana, tú no sabes que hemos tenido un hijo" (172). La emoción y la ternura ante este hecho devienen pronto en palabras de ternura para el pequeño bebé: "cosilla mía gelatinosa y amoratada; ven acá entre mis manos” (172). Andrés comienza entonces a explicarle a su hijo la forma en que él ve el mundo, pero, al no ver reacción por parte del nińo ante las explicaciones, las palabras se endurecen y opta por otra acción:

¿Pero qué es eso? No entiendes una sola palabra, no has podido escucharme una sola. Lo único que sabes es llorar y gritar con esa 
angustia de animalucho abandonado. ¡Para qué voy a decirte otras cosas de acá, hijo mío!

Mas está bien así. Como nada entiendes, sólo pareces una cosa. Je, Je.

Ven acá entre mis manos, que voy a concederte una gracia. Más estrecho, más estrecho aún...

-Andrés...

-Andrés...

- ¿Qué haces, Andrés...?

¿Eh? Yo... Yo... ¿Eh?

¡Pero mirad, mirad, gentes, cómo se ha hecho bruscamente de día! (174)

Entre sueño y vigila o lucidez y locura, el hecho es que Andrés asesinó a su propio hijo, un crimen atroz por el cual será encarcelado y llevado a juicio; en éste el protagonista se defenderá explicando que se trataba de un sueño solamente. Lo crudo del episodio muestra de qué manera Palacio lleva a extremos poco imaginables ciertas circunstancias que, sin embargo, se encuentran ahí, en la vida, como muchas otras. Algo similar ocurre con su cuento "El antropófago". En éste el protagonista mata a su esposa después de haberle cercenado los senos a dentelladas, para posteriormente también intentar comerse a su hijo (Palacio, 2000: 14-18). Lo interesante de todo esto es que tanto el narrador de "El antropófago" como el de Vida del ahorcado mantienen siempre un tono neutral frente a sus claras manifestaciones de bestialidad.

Aunado a lo anterior está la subversión. No se trata únicamente de ir en contra de lo establecido porque sí o de causar espanto, se trata de ser revolucionario y de llamar la atención sobre aquellas "otras" atrocidades que son acaso menos evidentes: la explotación de los seres humanos, la manipulación de las conciencias, la deshumanización. Andrés no sólo es un loco, también es un convencido socialista, un utopista que invita a todo el mundo a su "cubo", 
para compartir el mundo de seres libres. En lo que bien podría ser una digresión hacia su vida pasada, Andrés emite un fortísimo e incendiario discurso en contra de la sociedad burguesa y de la clase proletaria por igual. Comienza de la siguiente manera:

\section{«Camarada:}

Cuando estás delante del poderoso, ¿por qué tiemblas? Todo poder viene de ti. ¿Por qué no le escupes? ¿Por qué no le envileces con su misma pequeñez? ¿Por qué no le abofeteas?

¿Sabes que él esté hecho de otro barro que no sea un poco cosilla de miserias y vergüenzas?

¿Por qué te humillas? ¿Por qué?

Espera que la piara se dé cuenta de que la sordera del todopoderoso no tiene edad y verás cómo se viene -hambrienta e inflamada- y aprieta el cuello de los usurpadores. Y verás cómo les hace saltar los ojos, igual que a esos enanitos del celuloide. Y verás cómo goza la piara y se estira y se conforta.

Luego los grandes devorarán a los chicos y entonces tendrás que ponerte a temblar ante el nuevo poderoso, porque estás hecho de carne de esclavo (147).

Un último sentido que despliega la locura del narrador -aunque pueden existir muchos más- es el que se refiere a la tradición novelesca. Literatura y locura, es bien conocido, han ido de la mano prácticamente a lo largo de toda la historia. Ahora bien, sin tratar de enumerar el sinfín de obras a este respecto, iré directamente al caso más conocido, es decir, a Don Quijote de la Mancha de Cervantes. Al igual que sucede con Alonso Quijano, Andrés Farinango es un personaje que mira el mundo con una óptica distinta y, tal como sucede con el cervantino, el personaje palaciano intenta adecuar el mundo -y resolver las injusticias de éste- a su visión; evidentemente ambos fracasan a nivel individual, sin embargo, el destino de quienes asisten a sus aventuras toma, ya para siempre, otro cariz. 
Las similitudes, por tanto, se establecen no sólo por la condición mental de ambos personajes, sino también por la ruptura que, guardando toda proporción, ambas obras significaron en la historia del género novelístico, la tradición de la novela de caballerías y la del realismo-naturalismo de tipo burgués, respectivamente.

\section{La crítica y la ironía}

Pese a su brevedad, Vida del ahorcado encierra una multitud de sentidos y de direcciones, aunado a las nociones mencionadas en los apartados anteriores, existe una voluntad crítica sin cortapisa que se despliega durante prácticamente toda la novela. Como también ya se mencionó, la ideología profesada por el autor no es impedimento para que exponga los errores en que caen sus correligionarios; a este respecto me permitiré señalar sólo un par de episodios a modo de ejemplo.

El primero de ellos es el que lleva por título "LA REBELIÓN DEL BOSQUE", en éste fragmento asistimos a una sociedad de árboles antropomorfizados que hablan entre sí simulando una obra de teatro:

Coro de los Altos Pinos: Ay -patalean los altos pinos-, aquí nos tenéis de pie año tras año, hambrientos, octogenarios e inútiles, destinados a morir en este pobre jardinillo, cuando bien pudiéramos servir con ventaja en el transporte de mercaderías y en mil industrias útiles al progreso del siglo. ¡Protestamos en nombre de la libertad! (166).

Así sucesivamente los cipreses, los cedros, las palmeras; todos quejándose o protestando en contra de las protestas de los otros. Una vez encontrado un culpable común a todas sus desgracias -el hombre- se propone la revolución; algunos temerosos se pronun- 
cian en contra, otros, beligerantes, a favor. Los primeros en quejarse retoman la palabra:

Los PINOS: Señores, un momento. Un momento, señores. ¿No es verdad que estáis desvirtuando el verdadero sentido del movimiento? Ésta no es, no debe ser una revolución contra el hombre (murmullos del bosque); ¡ésta es una revolución contra el árbol! (parálisis del bosque). ¿Qué sacaríamos, en efecto, de destruir al hombre, si no por eso vamos a destruir nuestra condición de esclavos? Estamos aquí en calidad de árboles. Destruid esta calidad y habréis renovado vuestra condición de seres libres. Nuestro tirano es el árbol. Duro con él compañeros. Yo sirvo para el transporte económico de mercancías. ¡Abajo el árbol!

Coro de los Parásitos: No es verdad eso, compañeros: os están engañando miserablemente. Es el hombre vuestro enemigo. No les prestéis oído. ¡No les prestéis oído! ¡Abajo el hombre!

Los pinos: No tienen derecho para hablar los camaradas parásitos. Su palabra es sospechosa. ¡Tomadlo bien en cuenta y aplastad a los sinvergüenzas!

Las Palmeras: ¡Eso! Estos caballeros hablaron la verdad. Su concepción es profunda y llena de seso. ¡Ya lo vemos claro! Oírlo bien: el árbol es nuestro único enemigo. A quien debemos hacer la revolución a sangre y fuego es al árbol. Lo demás, pamplinas. Acompañadnos, camaradas: ¡abajo el árbol!

Los Pinos, dueños de la situación: ¡Abajo la tiranía! ¡Abajo el árbol!

El Bosque: ¡Abajoo!

El viento se retuerce entre los árboles. Todo el bosque eriza sus garrotes musgosos.

la Grama, a una Margarita Ocasional y Descarriada: ¡Agáchate! ¡Escóndete aquí! Espera que la tormenta pase. Los elementos están locos (167).

Reproduje el pasaje casi completo pues me parece de una elocuencia y mordacidad incomparables, se trata de la creación de 
una distopía -más de una década antes de Rebelión en la granja de Orwell-. Las interpretaciones al respecto podrían dar sin problemas mucho de qué hablar a sociólogos, filósofos e historiadores, no obstante, en lo que a este trabajo compete, sólo me limitaré a mencionar que su inserción en la novela le otorga a ésta una fuerte carga política.

Con una carga política similar, pero ahora sí mucho más en tono ideológico y directo de crítica al gobierno ecuatoriano, nos encontramos en el apartado "iATENCIÓN! iSUBASTA PÚBLICA!", donde se ponen a la venta los volcanes del país:

Atención, capitalistas del mundo:

El Chimborazo está en pública subasta. Lo daremos al mejor postor y se admiten ofertas en metálico o en tierra plana como permuta. Vamos a deshacernos de esta joya porque tenemos necesidades urgentes: nuestros súbditos están con hambre, por más que tengan promontorios a la ventana. Hoy es el Chimborazo, mańana el Carihuairazo y el Corazón; después el Altar, el Illiniza, el Pichincha. ¡Queremos tierra plana para sembrar caña de azúcar y cacao! ¡Queremos tierra para pintarle caminos!

Atención, capitalistas del mundo:

¡Los más bellos volcanes están en pública subasta! (149)

La crítica del pasaje también se orienta en otros sentidos. El primero tiene que ver con la voracidad del sistema capitalista -recuérdese que ya Martí, Rodó, o Mariátegui advertían del peligro de la política exterior de los Estados Unidos hacia América Latina- y su aprovechamiento de los países con menos recursos, esto sumado a la actitud entreguista de los gobiernos latinoamericanos. Se ve claramente, entonces, que la crítica desarrollada en la novela es sumamente potente y alejada del tono maniqueo. Lo irónico del fragmento se explica, pues es "El Gobierno de la República [quien] ha mandado insertar en los grandes rotativos del mundo esta con- 
vocatoria escrita en concurso por sus más bellos poetas" (148; las cursivas son mías).

Algo muy parecido sucede con los espacios en donde se desarrolla el argumento principal, es decir, los "cubos" y la corte; comencemos analizando el primero de ellos: "Ocurre que los hombres, el día una vez terminado, suelen despedirse de parientes y amigos y, aislándose en grandes cubos ad-hoc, después de hacer las tinieblas se desnudan, se estiran sobre sus propias espaldas, se cubren con mantas de colores y se quedan ahí, sin pensamiento, inmóviles, ciegos, sordos y mudos" (145).

La descripción que se hace de estos espacios queda en suspensión debido al lenguaje utilizado. El párrafo citado corresponde al inicio de la novela y cobra sentido sólo cuando llegamos al final de la misma. Como se sabe, Andrés es enjuiciado y condenado a la horca tras descubrirse que mató a su hijo; el cubo bien podría tratarse de una celda o de un cuarto de hospital psiquiátrico (teniendo en cuenta de que se trata de un hombre que se encuentra "desequilibrado" mentalmente). No obstante, la deliberada ambigüedad tiene que ver con un paralelismo con la vida común y corriente de los hombres, sus labores cotidianas y sin sentido, la geometría insulsa y aburrida de los habitáculos que se suelen usar como morada. Lo anterior queda de manifiesto más adelante: "He aquí un producto de las oscuras contradicciones capitalistas que está en la mitad de los mundos antiguo y nuevo, en esa suspensión del aliento, en ese vacío que hay entre lo estable y el desbarajuste de los mismos" (146).

Habitar un "cubo" tiene también que ver con lo paradójico del propio título de la novela. Vida del ahorcado señala ya una aparente contradicción, sin embargo, se trata de una alegoría con la vida de un hombre que se ha hecho consciente de su condición, que se ha dado cuenta que se está preso y sometido a lo absurdo de las leyes 
del mundo; así, cuando en el juicio le preguntan quién es, él sólo se limita a responder “_...ंyo?... Pues bien, soy un ahorcado" (180).

En cuanto al espacio de la corte el tono irónico llega a momentos de verdadero humorismo pero sin dejar a un lado la crítica. El juicio se escenifica en el penúltimo de los apartados señalado simplemente como "AUDIENCIA", entre muestras de repudio y hasta de violencia por parte de la muchedumbre congregada para ver sentenciado al filicida, Farinango se presenta ante el juez:

— Señores - repite a gritos el hombre en pie-: no creo que en los Anales del crimen de este pacífico y progresista país registren un caso de delincuencia igual al que nos tiene aquí congregados en demanda de justicia. La sociedad escandalizada, como un solo hombre ha venido a pedir castigo ejemplar contra el culpable. Tiembla la palabra en los labios y la lengua humana se resiste a pronunciar su nombre y a narrar el hecho nefando que lo retiene ahí, en el banquillo de los acusados, frente a la muda y conmovedora protesta de todo un pueblo honrado, cuyas fibras más íntimas han venido a estremecerse con el desarrollo de los suceso por todos los aquí presentes conocidos...

— ¡Bravoo! (177).

La parodia en el uso del lenguaje por parte del abogado que presenta el caso, su retórica hiperbólica y la forma en cómo reacciona el público ante ella nos hacen pensar en lo maniqueo que resultan los discursos oficiales y de qué manera es posible manipular a las masas inflamando sus más bajas pasiones. Es justamente la masa la que arenga al juez para que sentencie a la horca al enjuiciado. Esto ocurre tras la propuesta de absolución que propone al abogado defensor apoyado en el hecho evidente de que Andrés no se encuentra en sus cabales:

Sabios Jurisconsultos y distinguidos estudiantes de la Universidad aquí presentes convendrán conmigo en que, como se ha demos- 
trado ya plenamente, sólo existe delito en cuanto ocurran los tres elementos que el genial Carrara fijó con tanta precisión y sabiduría. Ya sabemos que en este caso nos falta el más importante de ellos, el discernimiento, y que por tanto no hay delito en manera alguna... El acusado debe ser absuelto...

Le interrumpe la muchedumbre:

- ¡Que se calle! ¡Que se calle!

— ¿Que se calle el vendido! (178).

El revuelo que ha causado la defensa convierte la sala en un caos de voces que indistintamente emiten juicios de valor, insultos al abogado, apelaciones a la autoridad para que el crimen no quede impune: “¡El pueblo tiene derecho! ¡Quiere defender su justicia!” (178). Ante tales circunstancias, como parecería lógico, el abogado defensor se queja de que el juez tome en cuenta la gritería de la masa, sin embargo, un representante de la Universidad toma la palabra y, tras un largo preludio rebosante de lugares comunes y retórica vacía, concluye que el acusado debe ser juzgado sin tomar en cuenta los elementos dispuestos por el defensor: "En el presente caso, debemos concluir, sin vacilaciones, que la ley no protege al ciudadano Andrés Farinango y que en consecuencia, el Juez, interpretando la voluntad del pueblo, debe aplicar el más eficaz y ejemplarizador método de supresión y defensa” (181).

Con la multitud enloquecida, los inútiles intentos del abogado defensor por devolverle algo de cordura al juicio, las disputas respecto al Código civil en vigencia, se le da la palabra al acusado: "Señor... Quería manifestar solamente al Honorable Tribunal que se trata de una lamentable equivocación. La respetable audiencia se ha dejado impresionar muy fácilmente... Eso del asesinato ha sido sólo un sueño... y, verdaderamente, no hay más Código que el de 1875 ” (182). Burlas y más acusaciones se suceden, la audiencia se ha convertido en un carnaval, ahora se acusa a Andrés, ya de bolchevique, ya de burgués -obviamente dependiendo de quién lanza 
la acusación, en una nueva crítica hacia la polarización radical en la sociedad-, todos piden que se le ahorque y el juicio termina con esa resolución pese a que la horca no es más un procedimiento en la impartición de justicia.

Poco más hay que añadir, los ejemplos citados muestran claramente -y una vez más- la forma en que Palacio ve la sociedad. No falta nadie, están expuestos: los abogados, la masa ciega, la justicia desorientada, la universidad cómplice y acomodaticia... Con base en este episodio, se ha querido ver en Palacio -en un nuevo traslado y como si toda literatura hecha en América Latina fuese deudora de la europea- una "actitud kafkiana”. Recordemos que El proceso fue escrito apenas siete ańos antes que Vida del ahorcado y que, además, Palacio ya había dado cuenta de lo caótico de la procuración de justicia, por ejemplo en "Un hombre muerto a puntapiés"; sin embargo, es posible que el autor tuviese noticia de la literatura de Kafka, sólo que por mi parte carezco de elementos para asegurarlo, en el caso que así fuese sería otro el lugar para intentar ver resonancias de la obra del praguense en la del ecuatoriano.

Lo que sí podemos notar es una especie de inversión de planos. En términos llanos, Andrés Farinango ha llegado al tribunal para ser juzgado por un crimen, un crimen atroz es verdad, no obstante, la institución encargada de procurar justicia se deja arrastrar por la opinión de la gente reunida en el recinto. Este hecho nos recuerda la crítica que ya en el siglo XVIII hacía Feijoo respecto a aquello de que "la voz del pueblo es la voz de Dios" (1980); la irracionalidad del crimen se ve opacada por la irracionalidad con que el pueblo exige justicia. La universidad, por otro lado, símbolo de la inteligencia y honestidad de un país, también se ve ridiculizada con el discurso de su representante que, disfrazado de analítico, sólo ofrece balbuceo y sinsentidos. 
La inversión, como se sabe, es uno de los procedimientos más recurrentes de la ironía; resulta, por ende, irónico que la sociedad congregada, heterogénea y, por lo mismo, desideologizada, sea la que finalmente juzgue a Andrés, justamente un luchador social y quien, debido a su condición, apenas se entera de lo que está pasando, como se observa en el párrafo siguiente:

Hola, hola, ¿estás ahí compañero Tixi? ¿Eres tú compatriota Alejandro?

Hola, Honorables Instituciones, ¡todas vosotras aquí representadas! Universidad, Tenderos, Prestamistas, Amantes, Trabajadores sin pan y más, y más.

Oh, ¿pero es que se trata de una fiesta deportiva que habéis traído aquí vuestras banderitas? Tal vez vais a batirlas como en los campeonatos de las Universidades Inglesas. Vaya, ¡qué cosa más interesante! Hola, hola, ¡tú aquí, mi dulce amigo Bernardo! ¡Bienatendino, Bienatendina! ¡Usted, señorita de los nopales! (177).

Mediante los ejemplos hasta ahora presentados, se puede vislumbrar el potente procedimiento crítico con que Palacio dota a Vida del ahorcado, aunado a la forma fragmentada y recursiva de la novela. Ambas características revelan una suerte de imagen que encuentra sentido en el título mismo de la obra: se trata de un instante donde el personaje está suspendido en la horca y alcanza a mirar lo que le rodea al tiempo que la cuerda que lo sostiene lo mueve caprichosamente, un instante en el que también recuerda lo que ha sido su vida y en el que, justo antes de morir, puede experimentar ese suceso compartido por todo ser humano.

\section{Consideración final}

Con el acercamiento propuesto a Vida del ahorcado, última novela de Pablo Palacio, he querido señalar aquellos aspectos que en mi 
opinión la hacen una lectura sumamente importante y necesaria para comprender el proceso seguido por la narrativa en nuestro continente. Existen múltiples señalamientos respecto a la incursión de la modernidad de la literatura en el ámbito latinoamericano, sin embargo, la mayor parte de los estudios se han enfocado en mostrar de qué manera la poesía tuvo un papel fundamental en este hecho; incluso los análisis de grandes escritores como Carlos Fuentes en La nueva novela hispanoamericana (1980), olvidan acaso en un afán por hacer descender nuestra tradición de la literatura europea o norteamericana- novelas tan importantes como la aquí estudiada.

Vida del ahorcado es un claro ejemplo donde se revela, por medio de la amalgama del tema crítico social y el vanguardismo compositivo, una forma nueva de hacer novelas en América Latina. Si se observa detenidamente la obra de Palacio, las no pocas acusaciones hechas hacia la novelística de la época (aquéllas que versaban en torno al maniqueísmo ideológico, la falta de indagación existencial, el monocorde tópico de la naturaleza avasallante, el descuido y la falta de realce del lenguaje, la recalcitrante solemnidad aunada a la falta de humor, entre tantas otras) quedarían abolidas, o al menos cuestionadas.,

En este trabajo, no ha sido mi propósito desmentir dichos esfuerzos, pero sí el poner de manifiesto que existen autores y obras que no han tenido la suficiente atención a pesar de que se traten, en mucho casos, de precursores del auge que posteriormente gozarían otras novelas identificadas ya como plenamente modernas. Los recursos, técnicas, configuraciones y tantas otras virtudes que sedujeron a la crítica, tienen unos orígenes inmediatos que es necesario recordar. 


\section{Bibliografía}

Baudelaire, Charles, 1995, "La modernidad", en El pintor de la vida Moderna, Alcira Saavedra (trad.), Murcia, Colegio de Aparejadores y Arquitectos técnicos/Librería Yerba/Cajamurcia, pp. 91-95.

Carrión, Benjamín, 2001, "Pablo Palacio", en La patria en tono menor, Gustavo Salazar (ed. y pról.), Quito/México, CCE/ FCE, pp. 67-78.

Corral, Wilfrido H., 2000, "Cronología”, en Pablo Palacio. Obras completas, W. H. Corral (ed.), ALLCA XX, Colección Archivos 41, Madrid, Barcelona, La Habana, Lisboa, Paris, México, Buenos Aires, Sao Paulo, Lima, Guatemala, San José, pp. 253-269.

Feijoo, Benito Jerónimo, 1980, Teatro crítico universal, Ángel Raimundo Fernández González (ed.), Madrid, Cátedra.

Fuentes, Carlos, 1980, La nueva novela hispanoamericana, 6a ed., México, Joaquín Mortiz.

Manzoni, Celina, 2000, "Una estética de la ruptura", en Obras completas, W. H. Corral (ed.), ALLCA XX, Colección Archivos 41, Madrid, Barcelona, La Habana, Lisboa, Paris, México, Buenos Aires, Sao Paulo, Lima, Guatemala, San José, pp. 447-464.

Palacio, Pablo, 2000a, "Vida del ahorcado (novela subjetiva)", en Obras completas, W. H. Corral (ed.), ALLCA XX, Colección Archivos 41, Madrid, Barcelona, La Habana, Lisboa, Paris, México, Buenos Aires, Sao Paulo, Lima, Guatemala, San José, pp. 143-184.

,2000b, "El antropófago", en Obras completas, W. H. Corral (ed.), ALLCA XX, Colección Archivos 41, Madrid, Barcelona, La Habana, Lisboa, Paris, México, Buenos Aires, Sao Paulo, Lima, Guatemala, San José, pp. 14-18. 
Paz, Octavio, 1990a, "Prefacio", en Los hijos del limo. Del romanticismo a la vanguardia, $3^{\text {a }}$ ed., Barcelona, Seix Barral, pp. 8-12. , 1990b, "La tradición de la ruptura", en Los hijos del limo. Del romanticismo a la vanguardia, $3^{\text {a }}$ ed., Barcelona, Seix Barral, pp. 15-37.

Robles, Humberto E., 2000, "Pablo Palacio: a punta de risa", en Pablo Palacio. Obras completas, W. H. Corral (ed.), ALLCA XX, Colección Archivos 41, Madrid, Barcelona, La Habana, Lisboa, Paris, México, Buenos Aires, Sao Paulo, Lima, Guatemala, San José, pp. 310-330.

Verani, Hugo, 1997, "Las vanguardias literarias en Hispanoamérica", Saúl Sosnowsky (ed.), Lectura crítica de la literatura americana. Vanguardias y toma de posesión, Caracas, Biblioteca Ayacucho, pp. 9-41. 